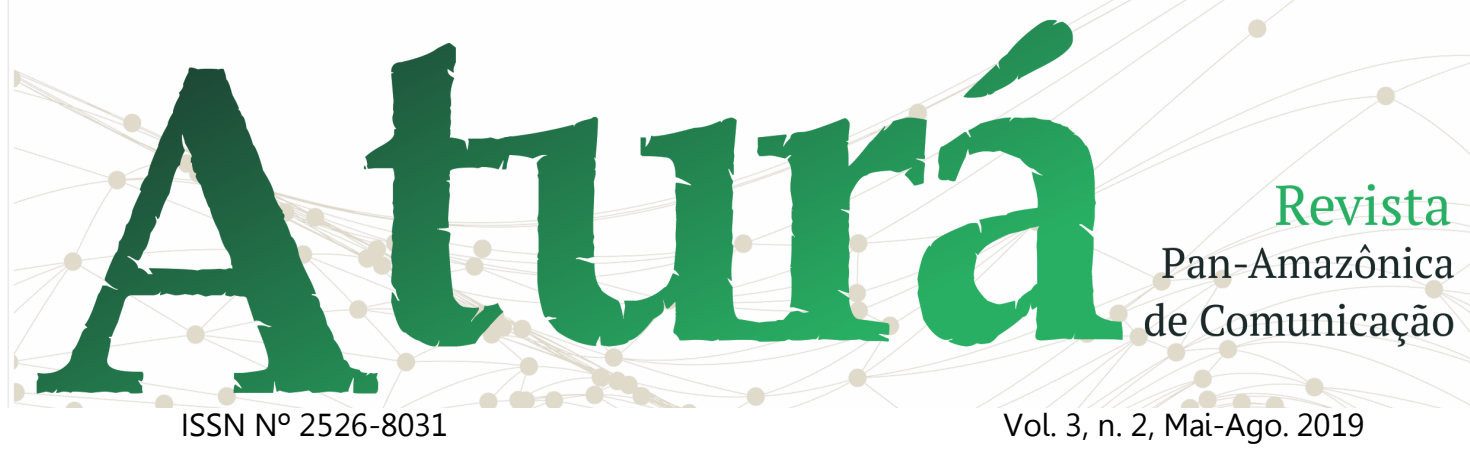

\title{
TERRITORIALIZAÇÕES DISCURSIVAS E DISPUTAS NARRATIVAS: Aldeia TabokaGrande e os carnavais de Taquaruçu em pauta
}

Discursive Territorializations and Narrative Disputes: Aldeia TabokaGrande and the Taquaruçu Carnivals

Territorializaciones discursivas y disputas narrativas: Aldeia TabokaGrande y los carnavales de Taquaruçu en agenda

\section{Anna Karolyne Souza Miranda ${ }^{1}$ Ana Carolina Costa dos Anjos ${ }^{2}$}

\section{RESUMO}

Seguindo a perspectiva de invenção de tradições de Eric Hobsbawm (2012) que, na contemporaneidade, conta com o discurso midiático como um elemento constitutivo do imaginário social, que produzimos esse artigo. Desse modo, apresentamos e discutimos três narrativas sobre a Aldeia TabokaGrande e eventos carnavalescos, no distrito Taquaruçu, da capital tocantinense, Palmas. As frentes que constroem o território discursivo são as do próprio produtor do evento, criador e idealizador da Aldeia, a dos moradores de Taquaruçu e o discurso midiático. Para tanto, se vale de uma criatividade metodológica com uso de Análise de Conteúdo, Análise de Discurso, Entrevistas semiestruturadas e Análise de Discurso do Sujeito Coletivo e encontra semelhanças e diferenças dessas frentes discursivas, demonstrando como há projetos distintos para narrativa da recente história de Taquaruçu, Palmas e Tocantins.

PALAVRAS-CHAVE: Disputa Narrativa; Discurso Midiático; Carnaval de Taquaruçu.

\footnotetext{
${ }^{1}$ Graduada em Comunicação Social/Jornalismo pela Universidade Federal do Tocantins. Diagramadora da Revista de Estudos Culturais do Programa de Pós-Graduação em Estudos Culturais da Escola de Artes, Ciências e Humanidades da Universidade de São Paulo (EACH/USP). E-mail: annaksmiranda@gmail.com.

${ }^{2}$ Graduada em Comunicação Social/Jornalismo (2012), mestre em Ciências do Ambiente (2015), ambos pela Universidade Federal do Tocantins, e doutoranda em Sociologia pela Universidade Federal de São Carlos. Atuou como professora substituta no colegiado de Jornalismo da UFT entre 2015 e 2017. E-mail: carolcdosanjos@gmail.com.
} 


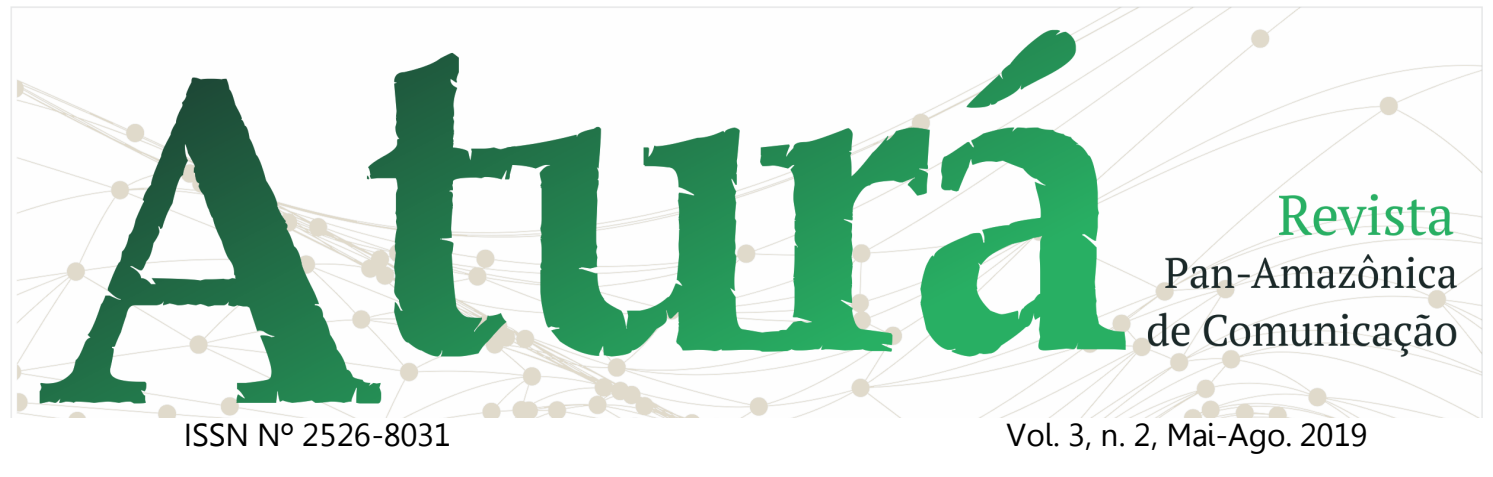

\begin{abstract}
From the perspective of invention of traditions of Eric Hobsbawm (2012) who relies on media discourse as a constitutive element of social imaginary in contemporary times, this article was developed. Thereby, we present and discuss three narratives about the Aldeia TabokaGrande and carnival events in the Taquaruçu district of the Tocantins capital, Palmas. The fronts that build the discursive territory are those of the event's own producer, creator and creator of the Aldeia, the residents of Taquaruçu and the media discourse. To this end, it uses methodological creativity using Content Analysis, Discourse Analysis, Semi-structured Interviews and Collective Subject Discourse Analysis and finds similarities and differences in these discursive fronts, demonstrating how there are distinct projects for the narrative of recent history of Taquaruçu, Palmas and Tocantins.
\end{abstract}

KEYWORDS: Narrative Dispute; Media speech; Taquaruçu Carnival.

\title{
RESUMEN
}

Siguiendo la perspectiva de invención de tradiciones de Eric Hobsbawn (2012) que, en la contemporaneidad, cuenta con el discurso mediático como un elemento constitutivo del imaginario social, producimos este artículo. Deste modo, presentamos y discutimos tres narrativas acerca del pueblo TabokaGrande y eventos carnavalescos en el distrito de Taquaruçu, de la capital de Tocantins, Palmas. Las frentes que constituyen el territorio discursivo son las del propio productor del evento, creador y idealizador del pueblo, la de los moradores de Taquaruçu y el discurso mediático. Para tanto, nos valemos de una creatividad metodológica con el uso de la Análisis de Contenido, Análisis del Discurso, Entrevistas semi-estructuradas y Análisis del Discurso del Sujeto Colectivo, y encuentra semejanças y diferencias entre esas frentes discursivas, demostrando como hay proyectos distintos para la narrativa de la reciente historia de Taquaruçu, Palmas y Tocantins.

PALABRAS CLAVE: Disputa Narrativa;. Discurso Mediático; Carnaval de Taquaruçu.

Recebido em: 24.02.2019. Aceito em: 24.04.2019. Publicado em: 01.05.2019. 


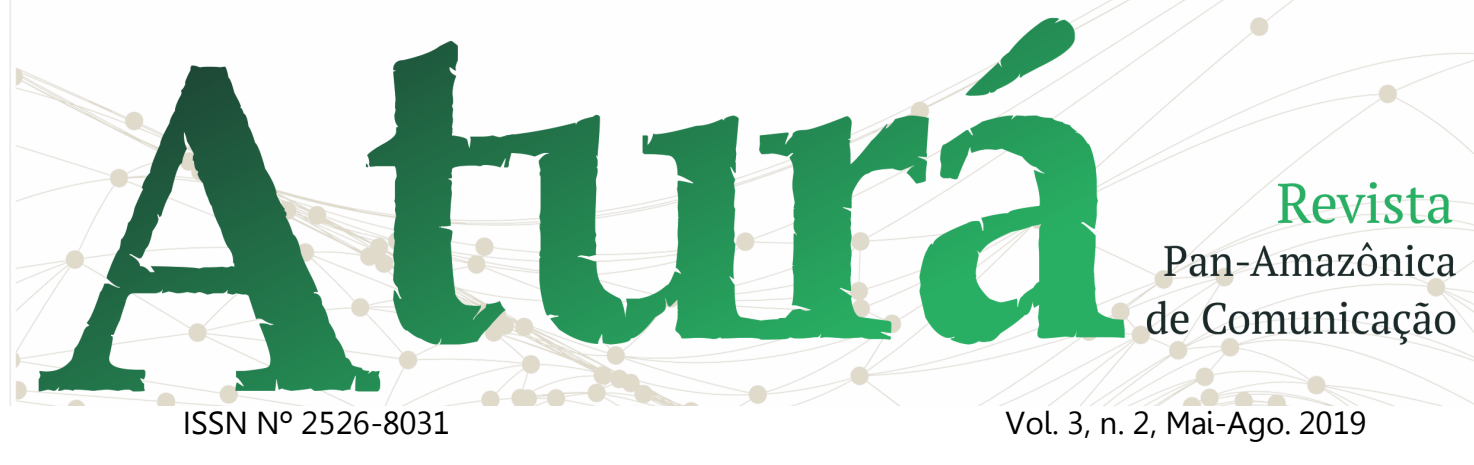

\section{Introdução}

As disputas de narrativas sobre os fatos e feitos sociais, como a construção de uma nação, por exemplo, não é um fenômeno novo ${ }^{3}$. Neste texto, que é uma síntese de uma monografia de graduação, buscamos captar algumas narrativas dispostas e em disputa no tecido social sobre um evento que ocorre durante os carnavais em Taquaruçu (distrito da capital do Tocantins, Palmas), especificamente na Aldeia TabokaGrande. A saber, analisamos as narrativas nativas, isto é, o que o sujeito que promove o evento $^{4}$ e reside na Aldeia constrói sobre si, como a população de Taquaruçu se refere ao evento e à Aldeia e como o discurso da mídia impressa local retrata sujeito, Aldeia e evento.

O próprio Estado do Tocantins, enquanto unidade federativa e história oficial, é novo, criado em 1988 e com a capital criada a partir do nada em 1989. Isso, por si, já denota um campo com narrativas em disputas, uma vez que os

\footnotetext{
3 A História, enquanto teoria, metodologia e disciplina, também tem suas disputas travadas no início do século $X X$ entre positivistas, marxistas e seguidores dos Annales. Todavia, como esse não é o intuito do trabalho, apontamos apenas que neste texto nos valemos dos pressupostos do historiador marxista Eric Hobsbawm (2012).

4 Destacamos que, ao longo do texto, denominamos evento, manifestação ou fenômeno para descrever e analisar as ações que acontecem na Aldeia TabokaGrande durante o carnaval palmense.
}

personagens que participaram da criação/invenção do Estado e sua capital seguem movimentando as peças desse jogo simbólico-político. Dessa maneira, aqui tratamos um fragmento da história do tempo presente de Taquaruçu-Palmas.

Assim, Taquaruçu primeiro foi um povoado (1940-1960), distrito de Porto Nacional. Depois, cidade, Taquarussu do Porto (janeiro de 1988 a dezembro de 1989) (GOIÁS, 1988; PALMAS, 1989). Após isso, novamente foi distrito, Taquaruçu, da capital Palmas, a cidade sem passado ou memória. Assim, então, tornou-se o Admirável Vale das Águas sob a guarda da capital que se volta ao distrito, articulando políticas públicas que ressignificam a comunidade e afetam diretamente a ordem econômica e social de sua população ${ }^{5}$.

As constantes rupturas que essa comunidade tem vivenciado criaram um terreno propício para o processo de invenção de tradições, conceito cunhado por Hobsbawm (2012). E foi nesse terreno

\footnotetext{
${ }^{5}$ Um exame mais amplo de tal contexto pode ser encontrado em "A Invenção de Tradições na Capital mais jovem do Brasil: a Aldeia TabokaGrande", monografia escrito por Anna Karolyne Souza Miranda (2017) e orientado por Ana Carolina C. dos Anjos, trabalho que serve como base para este artigo. Assim como em Carvalho (2010), que realiza um apanhado dos ciclos econômicos do distrito, ou ainda em Campos (2015), que traça um olhar sobre o imaginário social da comunidade a partir de trajetórias discursivas.
} 


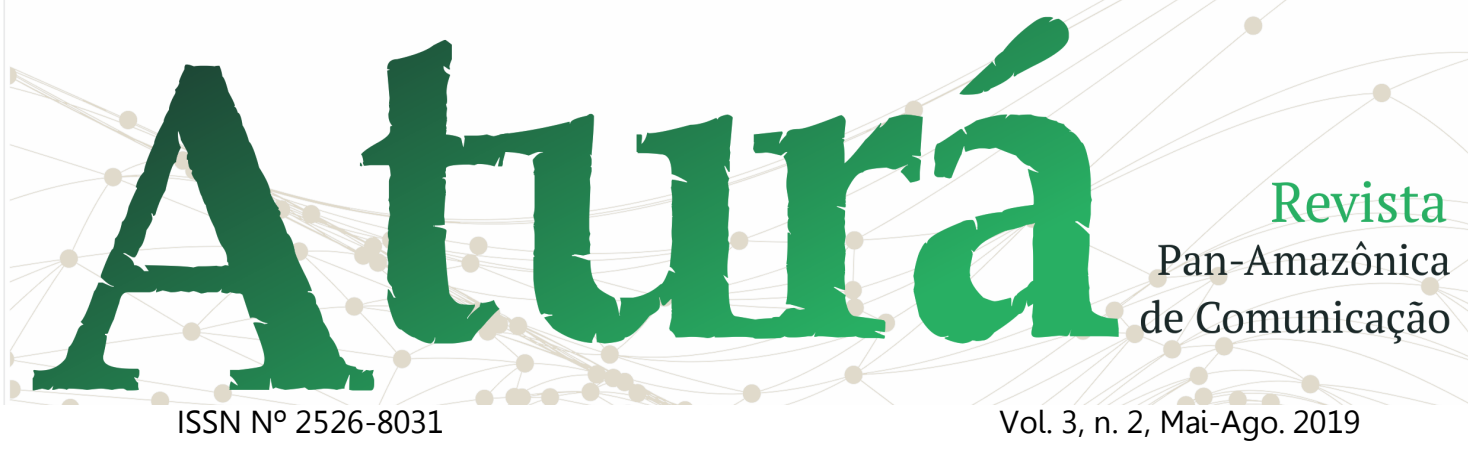

fértil que o corpus desta pesquisa floresceu e tem sido apreendido por diferentes instâncias discursivas. Assim, é sobre algumas delas que esse trabalho se debruça.

Realizado em caráter exploratório, o estudo utilizou ferramentas multimetodológicas (MARCONI; LAKATOS, 2003) para a composição de seus três eixos: uma perspectiva endógena, isto é, o que o idealizador da Aldeia TabokaGrande diz sobre si; a percepção da população local (do distrito de Taquaruçu) tem sobre a Aldeia e os eventos que ela promove e o discurso midiático local tecido sobre o fenômeno (eventos da Aldeia TabokaGrande). Cada um dos eixos compõem um vasto material de características peculiares e discrepantes, dessa maneira, para a coleta e análise, fez-se necessário o uso de um aporte metodológico próprio em cada segmento. Sendo assim, para apreender a Aldeia a partir da narrativa de seu mentor, Wertemberg Nunes, foram feitas uma série de entrevistas semiestruturadas inspiradas pela metodologia da História Oral (FERNANDES, 2005).

Já a percepção da população de Taquaruçu sobre o fenômeno foi levantada utilizando-se de entrevistas também semiestruturadas com membros da população local. As pessoas foram escolhidas com base no conceito de guardiões de memória definido por
Gomes (1996) e divididos em dois grupos geracionais orientados pela trajetória histórica da comunidade descrita por Campos (2015). As narrativas tecidas por esses representantes da população sobre a Aldeia TabokaGrande e suas manifestações foram compiladas em um discurso do sujeito coletivo e analisadas com base no método Análise de Discurso do Sujeito Coletivo de Lefevre; Lefevre (2012).

Em seguida, no terceiro eixo, para investigar como o discurso midiático formulado por jornais impressos representou as manifestações culturais promovidas pela Aldeia TabokaGrande, nos valemos de Análise de Conteúdo e Análise de Discurso. Analisamos um material documental composto por reportagens veiculadas, no período de 2001 a 2017, pelo Jornal do Tocantins e Jornal Primeira Página, acerca dos eventos carnavalescos realizados em Palmas.

Tais veículos foram escolhidos pela periodicidade e representatividade histórica, estando em atividade ininterruptamente desde 1979 e 1985, respectivamente, 0 que os configura como exceção na história da imprensa tocantinense. O recorte do corpus foi feito utilizando a ferramenta da Análise de Conteúdo Unidade de Registro, proposta por Laurence Bardin (2009). Tendo feito o recorte, obtemos a 


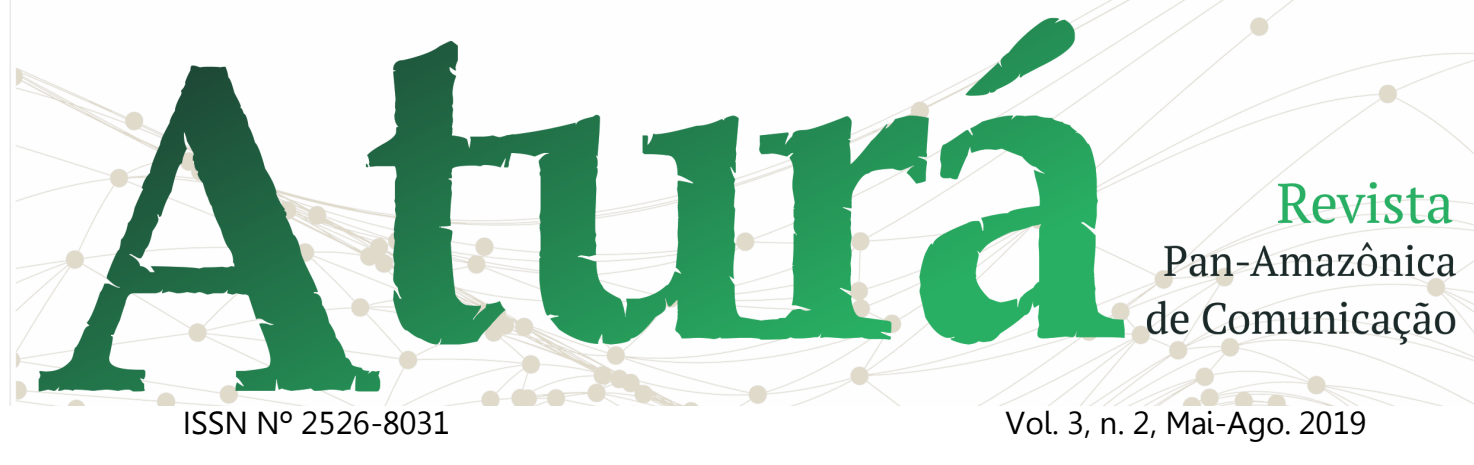

amostra/universo, que foi tabulada, para então se formar a amostragem, porção analisada com ferramentas da Análise de Discurso (AD). Entretanto, não foi empreendida uma análise clássica, isto é, foram utilizados os pressupostos metodológicos da $A D$ segundo Orlandi (1999) e Pinto (2002).

Após ser materializada e existindo através dos anos, a Aldeia, junto a suas manifestações culturais, ganha espaço no imaginário social, sendo apropriada pelo discurso midiático e significada de diferentes formas pela população local. Isso fica demonstrado nos resultados obtidos, nos quais ficam evidentes disparidades e consonâncias entre as construções discursivas produzidas pelos diferentes eixos com relação ao objeto de estudo.

Com isso apresentado, para apresentar os três eixos ou territorializações discursivas, propomos uma divisão narrativa, com fins meramente didáticos, pois, no cotidiano, os discursos se sobrepõem, distanciam e intercalam concomitantemente. Dito isso, começamos pelo sujeito, suas ações e a Aldeia.

\section{O sujeito, a aldeia e sua manifestação}

Para descortinar o objeto de pesquisa, recorremos ao sujeito Wertemberg Pereira Nunes. Ele é pai da família Tawera ${ }^{6}$, mestre de cultura popular e mentor da Aldeia TabokaGrande, para a qual traça uma gênese que se inicia junto ao seu próprio percurso de vida, ainda na década de 1960, com a infância no interior do que se tornaria o estado do Tocantins.

Nascido em lugar que não existe mais, segundo o interlocutor, - em referência a alteração de estado federativo sofrida pela cidade de Gurupi (antes pertencia ao Goiás e, após 1988, passa a pertencer ao, então criado, Tocantins) - , Wertemberg passou os primeiros anos de sua infância em Ponte Alta do $\mathrm{Norte}^{7}$, período idílico de encantamento com o mundo. A terra, os córregos, os animais e as histórias sobre a Boiúna contadas pela mãe são elementos centrais na formação do $\mathrm{Eu}$, da identidade como ser humano e tocantinense. Tal período se encerra com a mudança da família para Porto Nacional, que representou a passagem à adolescência.

Relativamente urbanizada, Porto Nacional, na época, era referência econômica, histórica e cultural para a

\footnotetext{
${ }^{6}$ Acrônimo criado por Wertemberg a partir da primeira sílaba dos nomes de seus filhos mais velhos: Taiom, Wertemberg Jr. e Ramar. O nome artístico é uma marca da família, tendo exercido influência inclusive na escolha do nome da caçula: Wene.

7 Atualmente, município de Ponte Alta do Tocantins. A alteração do nome se deu em função da criação do estado em 1988.
} 


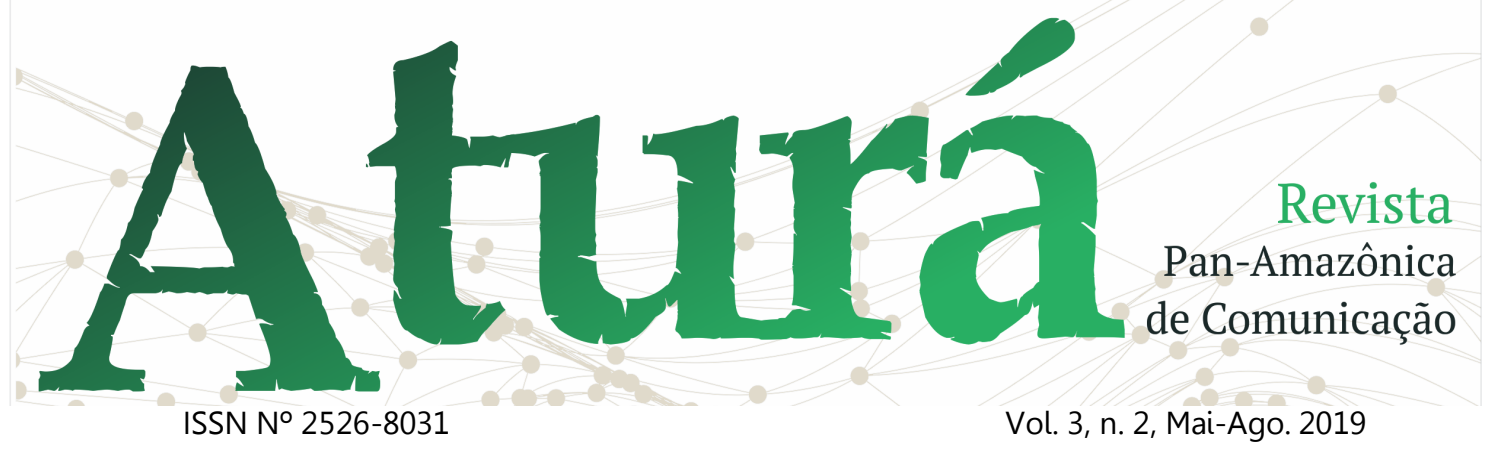

região; e seu movimento comercial atraia também atrações artísticas. Dessa maneira, o jovem passa a ter contato com o cinema, o circo e o teatro; e esses contatos artísticos o fazem vislumbrar uma vida dedicada à arte, o que o impele a se mudar novamente, dessa vez em deliberação própria. Deixou a família e partiu sozinho para Goiânia; cidade grande, grandes possibilidades. Durante os anos de 1970, o Tocantins permanecia anexado a Goiás, e Goiânia era a capital que, apesar do distanciamento, representava o ideal de cidade grande ${ }^{8}$.

$\mathrm{Na}$ época, a efervescência política e cultural do país contribuiu para seus interesses e trajetória. Durante as décadas de 1980 e 1990, dedicou-se às artes cênicas: atuou, escreveu, dirigiu, estudou e pesquisou de forma orgânica; construindo a sua própria visão de teatralidade, enquanto dramatizava as durezas. Sobre esse percurso, descreve que foi "pegando uma coisa aqui, outra

\footnotetext{
${ }^{8}$ Ao tentar reunir agência e estrutura, inserimos a história de nosso personagem no movimento conhecido como êxodo rural, no Brasil, no qual populações rurais eram 'expulsas' para o meio urbano. Ou seja, além da deliberação tácita de Wertemberg, há um movimento sócio-político e econômico que está acontecendo em nível de Brasil. Conforme Camarano; Abramovay (1999), $40 \%$ da população que residia nas áreas rurais migraram para centros urbanos durante a década de 1970. Outro adendo importante são os movimentos culturais concentrados nas "cidades grandes" em plena contestação à ditadura militar brasileira.
}

coisa ali. Fui juntando, pesquisando, mesmo sem nunca ter estudado. Fui ligando as coisas até ter minha ideia, minha visão" (NUNES, 2017, em entrevista).

Entre suas principais referências artísticas, Wertemberg aponta as produções de Maria Clara Machado para o teatro infantil, Benjamim de Oliveira, conhecido como o primeiro palhaço negro do Brasil, e o dramaturgo italiano Carlos Goldoni, no campo das máscaras. Também destaca que, para a concepção e confecção das suas próprias criações, pesquisava as expressões faciais em filmes e andando nas ruas. A partir dessas observações, o artista buscava a compreensão cultural dos elementos universais como a alegria, o riso e a tristeza.

Além da profissionalização artística, esse período proporcionou também uma formação como produtor e empreendedor cultural, o que the rendeu segurança financeira como prestador de serviços cênicos para empresas. Porém, quando o viver de teatro se materializou, trouxe consigo a inconformidade que 0 levaria a uma nova mudança.

A estabilidade perdia espaço ao desejo de autoafirmação artística e pessoal que aflorava e, então, o artista se propõe uma aventura: "Eu queria testar se as pessoas gostavam do meu trabalho só por me conhecer. Saber se aquilo que 


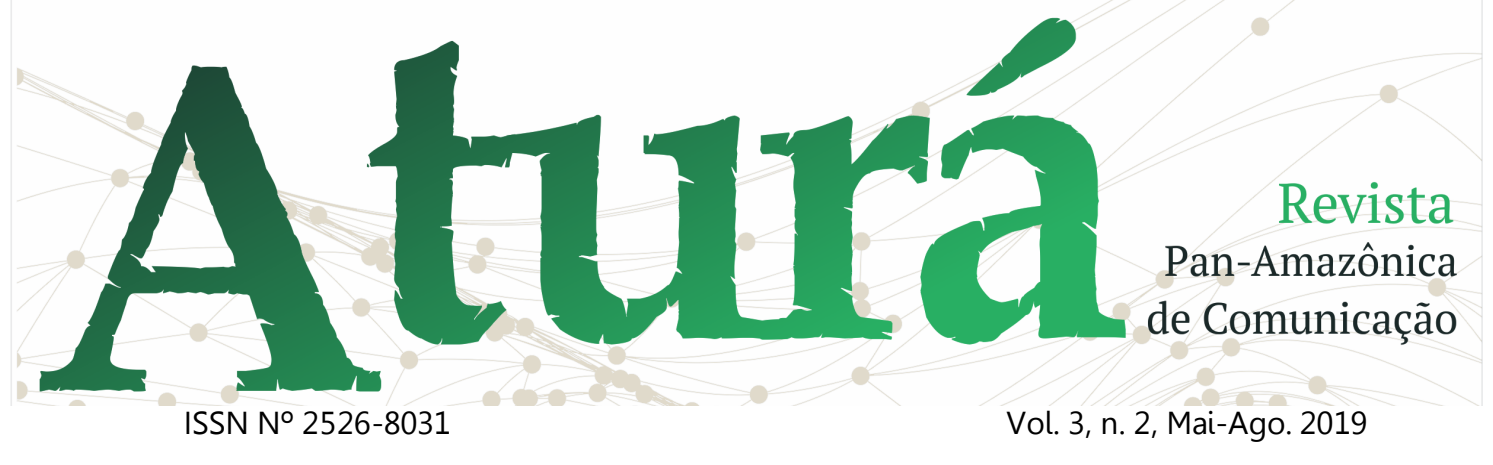

fazia tinha valor em outros lugares só pelo que era" (NUNES, 2017, em entrevista).

Após um curto período em Brasília, o mestre e sua família partem para terras desconhecidas e aportam no litoral do Espírito Santo, montando acampamento em Vitória, capital capixaba. Tal empreitada sabática é batizada de Expedição Humanação. Essa jornada exploratória tinha um objetivo bem consciente: "conhecer o desconhecido sem ser reconhecido". Wertemberg queria saber como as pessoas ali viviam sua realidade diária e se sua arte teria espaço e reconhecimento ali, no "desconhecido".

Durante essa empreitada, o mestre dispunha de tempo para experimentações que culminaram na construção de seus bonecos e no desenvolvimento do capoeboicongo, ritmo musical de sua autoria que é executado por tambores e berimbaus que conduz as cerimônias da Aldeia TabokaGrande. O capoeboicongo é uma construção que mescla musicalidades e instrumentos utilizados em capoeira, boi bumba e congada.

Realizando apresentações de rua, Wertemberg foi gradativamente ganhando espaço em território capixaba. Entretanto, junto ao reconhecimento, veio também o estranhamento:

\begin{abstract}
Vou te contar o que aconteceu pra você ver o tanto que a minha raiz aqui com o Tocantins é forte. Aí fui e fiz as máscaras de palhaço, botamos as máscaras e fomos fazer o show, aí o público chegava e: olha o camaleão, olha o não sei mais o que, olha o índio. A única coisa que eles não chamou nós (sic) foi de palhaço, pra você ver o tanto que o meu traço não tinha nada a ver. (...) Então o próprio povo me mostrou que eu não era, não batia com aquilo ali. (NUNES, 2017, em entrevista)
\end{abstract}

As experiências de estranhamento foram o gatilho para o desejo de retorno à terra natal, para si enquanto indivíduo artista. Porém, o retorno para o Tocantins, no ano 2000, longe dos grandes centros urbanos da região sudeste, impôs dificuldades para o artista. Inicialmente, ele atuou como professor de teatro, em projetos sociais no distrito de Taquaruçu onde se instalou de forma provisória, com planos de firmar residência fixa no centro da capital Palmas - planos que nunca concretizou.

Palmas fora deliberada de gabinetes políticos e delineada em pranchetas e maquetes, instalada no território de Taquaruçu, em 1990, e assimila sua condição de município e sua classe política eleita em 1989. Concomitante à construção da Última Capital Planejada do Séc. XX (SILVA, 2010), narrativas foram tecidas e monumentos foram construídos, mas a ausência de temporalidade se faz constante na tentativa de compor e se conectar com um imaginário social, 


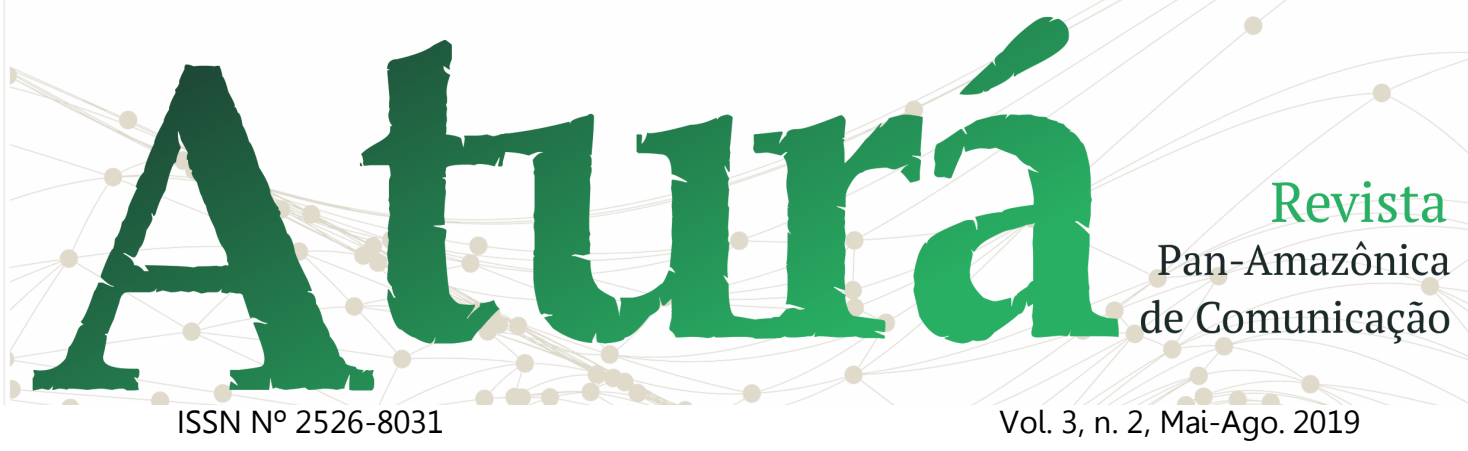

empreendimento que se fez parte dos projetos políticos, tanto dos prefeitos palmenses quanto dos governadores tocantinenses (ANJOS, 2017; SILVA, 2010).

Concomitante a chegada de nosso personagem à cidade, a partir de 2001, a gestão da prefeita Nilmar Ruiz (2001 2004), terceira prefeita eleita, voltou suas atenções para o povoado, promovendo pequenas reformas e instalando o polo ecoturístico em Taquaruçu. Como parte do plano de incentivo turístico, foram destinados recursos para a montagem de atrações artísticas durante o carnaval daquele ano. Essas foram as condições que propiciaram o nascimento da Aldeia TabokaGrande, inicialmente um bloco de carnaval que foi sendo estruturado como um ponto de cultura com o passar dos anos.

Localizada aos pés da serra de Taquaruçu, a Aldeia é um local aberto, apesar do difícil acesso devido o relevo e o trecho sem calçamento que precede a entrada. Enquanto espaço físico, serve como casa e ateliê do artista, onde também são realizadas oficinas de confecção de bonecos e tambores. Porém, ao longo do ano, o local se transforma em espaço cerimonial, no qual são realizados rituais entre os quais a Queima dos Tambores e Corte da Boina durante o carnaval, que são os mais antigos e populares.
Em 2001, o então bloco TabokaGrande contava apenas com quatro personagens- bonecos: o Amarelo, - Tabocão, a MãeBá e a Boiúna. Essa última é uma figura mítica que é procurada pelos galos durante o cortejo e possui íntima relação com o imaginário do mestre. Seus primeiros contatos com a cobra com cabeça de boi ocorreram ainda na primeira infância, nas histórias de sua mãe. A cobra gigante que vive no fundo do rio possui chifres e serpenteia animada por mulheres, recorrente em contos sertanejos e do universo dos encantados.

Entre os bonecos, Amarelo é o mais antigo, criado ainda em Vitória, Espírito Santo. Seu nome e cor fazem referência às pessoas e suas dificuldades como a fome. Por outro lado, o Tabocão já nasceu para o bloco, como homenagem à comunidade já que o termo Taquaruçu possui origem indígena e significa "taboca grande".

Após seu início, as manifestações continuaram em processo de criação, se metamorfoseando a cada ano. Wertemberg explica que atualmente os habitantes da Aldeia TabokaGrande são mais numerosos, a começar pelos bonecos gigantes, que, desde 2005, são cinco. Conhecidos como Os Galos de Palmas, representam as regiões da capital. 


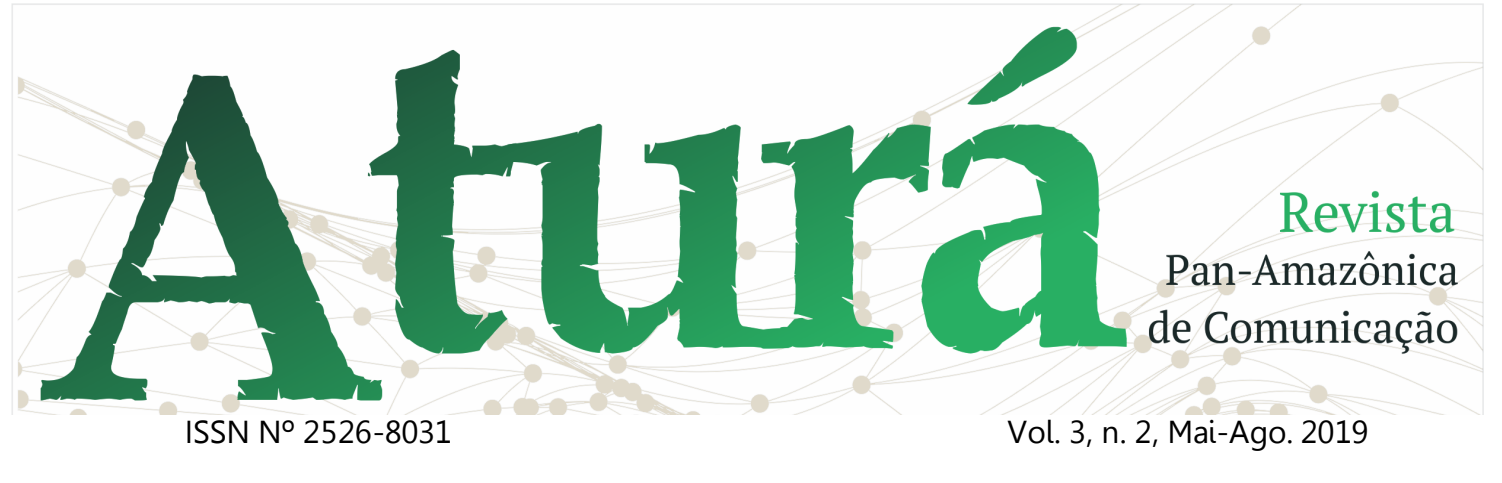

Sobre os bonecos, o TabokaGrande é o anfitrião da cerimônia. Ele representa a região de Taquaruçu. Marandukã, por sua vez, representa a região central da capital, a área projetada conhecida como plano diretor. Já o boneco Galo Alto faz referência à região de Taquaralto e simboliza o grande movimento do comércio local espontâneo. A região dos Jardins Aureny é simbolizada pelo Imperioso. Enquanto isso, o boneco União representa os moradores da região norte de Palmas, área à margem, conhecida também como Vila União (ver Figura 1).

Figura 1 - Os Bonecos da Aldeia TabokaGrande

Fonte: Autoria desconhecida (s/d). Acervo da Aldeia TabokaGrande.

Além dos já citados, existem ainda outros personagens que compõem o rito, tais como o Cobaçu. Trata-se de um homem vestido com palhas de babaçu. $\mathrm{O}$ personagem era originalmente animado pelo pai de Wertemberg e lembra aos participantes a íntima relação do coco com a história de Taquaruçu ${ }^{9}$.

A cerimônia como um todo é composta por dois momentos distintos: o cortejo ou caçada da Boiúna e a Queima dos tambores. Apesar das alterações corriqueiras, o cerne do ritual inicial é a interação dos bonecos Galos de Palmas com a Boiúna, são tocadas canções e feitas danças em meio ao público que interage com os personagens. $O$ mestre afirma que a relação dos personagens representa a dualidade do femininomasculino, o encontro das águas com a terra, representados respectivamente pelos bonecos e a Boiúna.

O ritual de Queima dos Tambores se inicia com uma breve explicação sobre - caráter purificador do fogo e o simbolismo incutido no ato de queimar coisas ruins como veículo de renovação

\footnotetext{
${ }^{9}$ Cobaçu tem uma performance imagética que se assemelha a uma tradicional festa tocantina (também comum em interiores do Brasil), os caretas de Lizarda, sendo tema de documentário do produtor e diretor Marcelo Silva, já exibido em solo francês, dentro da programação Ano do Brasil na França. Os caretas são pessoas, geralmente do gênero masculino, que usam máscaras e cobrem seus corpos de palha e saem nas ruas do município durante o feriado da Sextafeira da Paixão. Entre o sagrado e o profano, apregoam medo nas pessoas. Além disso, como tema de uma outra tessitura, há uma semelhança com o orixá Obaluaê (também conhecido como Omulù ou Xanapã, no Candomblé, Umbanda ou Batuque, no sincretismo São Roque ou São Lázaro) que rege as enfermidades e os espíritos, filho de Oxalá e Nanã.
} 


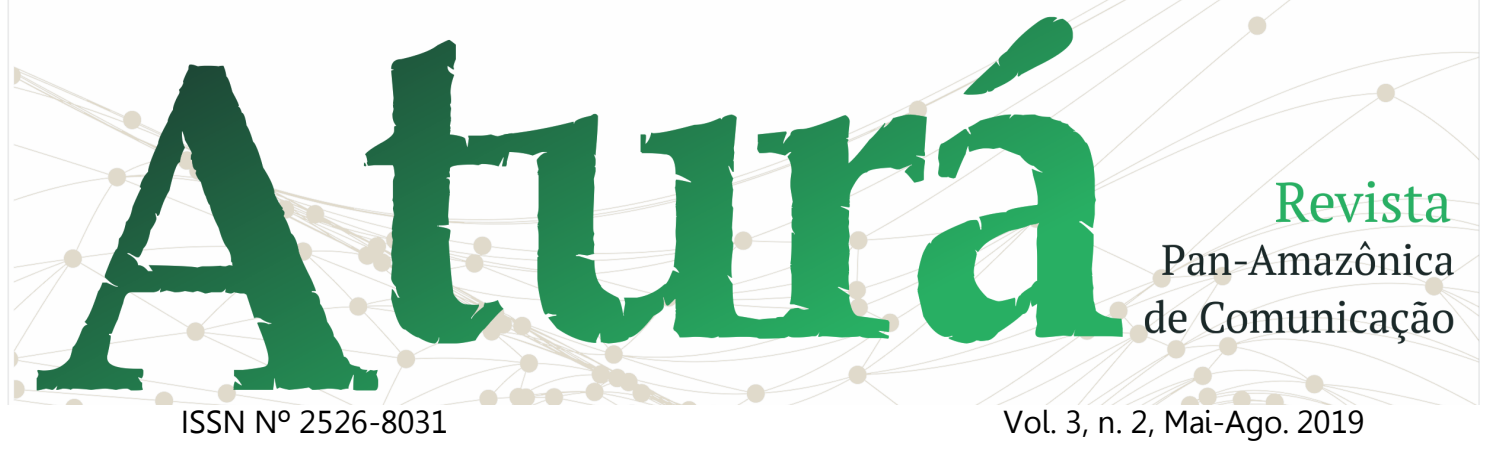

espiritual. Wertemberg convida os participantes que estão dispostos em um círculo a depositarem seus desejos materiais e imateriais nas toras ocadas, chamadas de turimbó, que serão acesas como parte do ritual. Com as piras já acesas, entoam-se cânticos e os membros da banda empunham seus tambores rentes ao turimbó e o couro próximo às labaredas recebe toques ritmados (ver Figura 2).

Figura 2 -Cerimônia da Queima de Tambores em dois atos

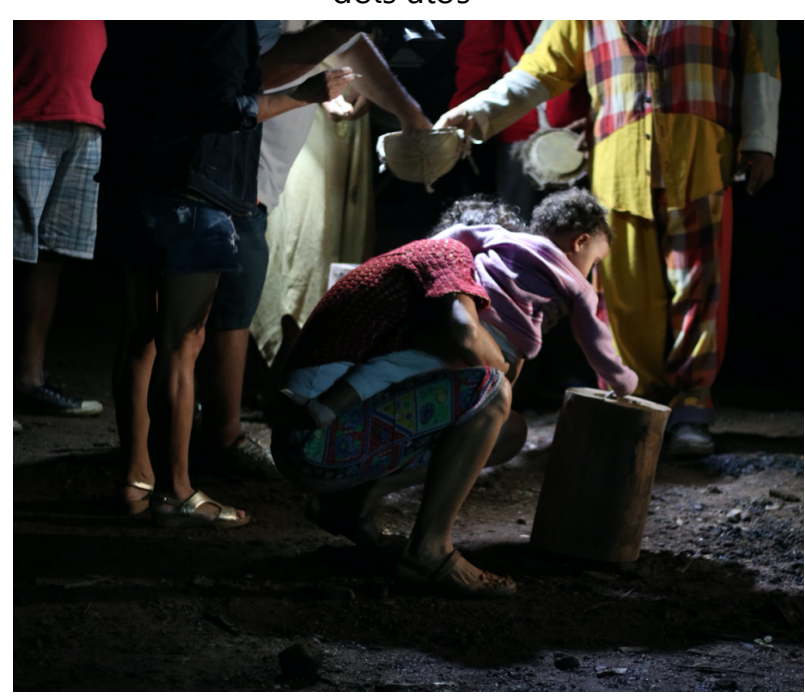

Fonte: Miranda (2017).

A música animada irrompe novamente, encerrando o tom meditativo, enquanto os participantes se dispersam. Nesse momento, o mestre é muito solicitado, recebendo cumprimentos e tirando fotos. É comum que parte do público continue no terreiro dos Tawera por algum tempo revendo rostos conhecidos e conversando.

Figura 2 - Cerimônia da Queima de Tambores em dois atos

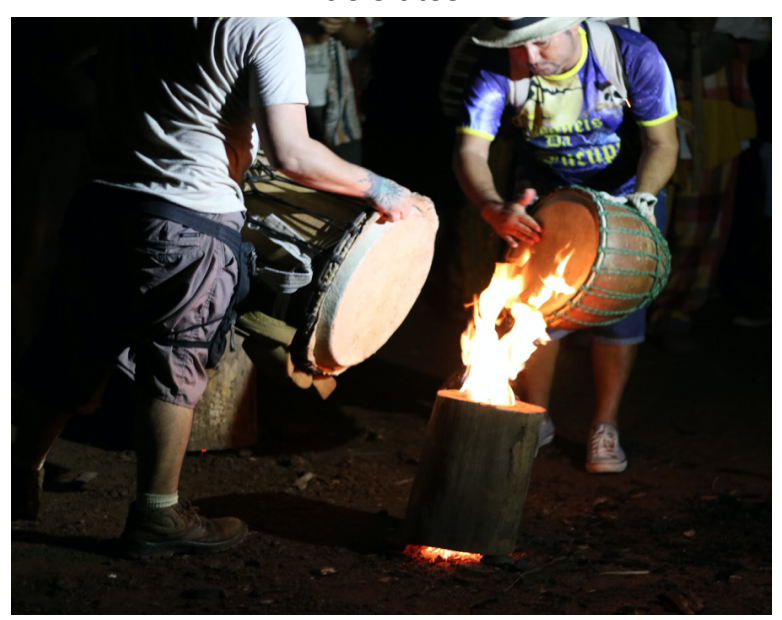

Fonte: Miranda (2017).

Para além dos elementos ritualísticos, outro fator que sofreu mudanças fundamentais nos dezenove anos em que ocorre o evento foi o apoio financeiro efetuado pelo poder público municipal. O mestre explica que os subsídios sempre estiveram ligados à contratação de serviços, como o show da banda TabokaGrande ou o evento nas ruas animado pelos bonecos gigantes. Porém, ao longo dos anos, o financiamento foi se tornando cada vez mais escasso, se extinguindo nos anos de 2017 e 2018 e sendo restabelecido em 2019.

O relato de Wertemberg pode ser entendido a partir da observação da relação que a Prefeitura de Palmas 


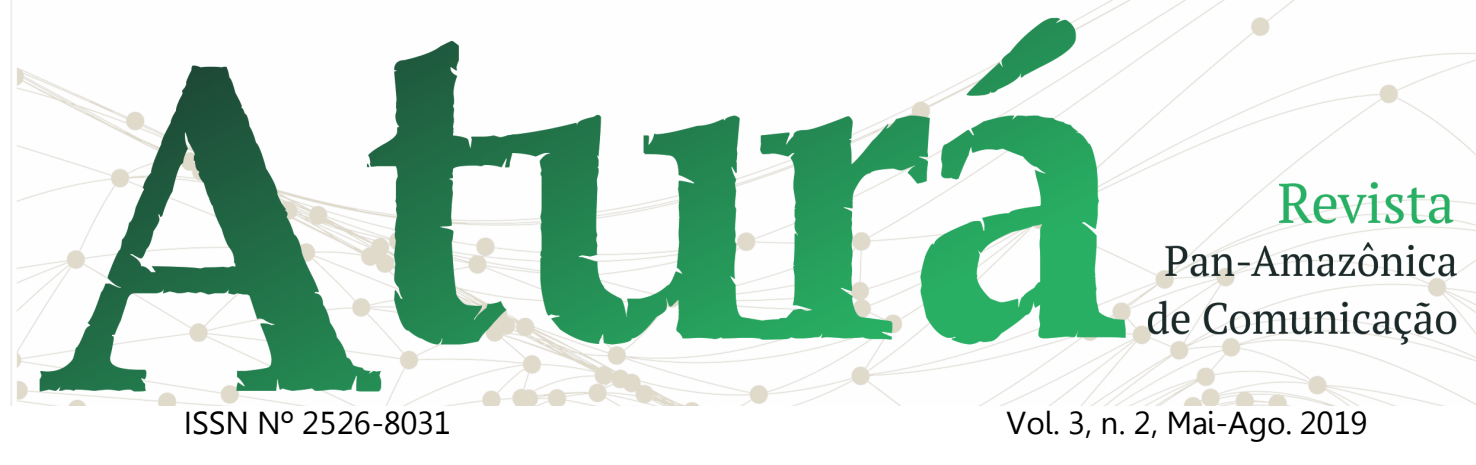

construiu com as festividades carnavalescas, nesse período. O financiamento massivo de diversos tipos de atrações - entre trios elétricos e blocos de rua - que se iniciou em 2001, na gestão de Nilmar Ruiz, durou até 2010 . A partir de 2011, a prefeitura, sob alegação de dificuldades financeiras, deixou de financiar diretamente a programação, se valendo de editais de apoio às iniciativas independentes, situação que se repetiu em 2012.

Sob a gestão de Carlos Amastha (2013 - abril de 2018), o executivo palmense voltou a financiar diretamente a festa popular, em 2013 - ano em que foi realizada homenagem à Aldeia TabokaGrande. O carnaval Todos os Ritmos uma só Alegria foi aberto oficialmente durante um ritual na Aldeia em Taquaruçu. Porém, a partir de 2014, o posicionamento institucional da Prefeitura de Palmas muda drasticamente, se voltando a uma comemoração religiosa, essencialmente cristã, em suas denominações católicas e protestantes. Fora instalado o Palmas Capital da Fé e as demais atrações e manifestações culturais populares perderam o espaço na programação oficial financiada por verba pública $^{10}$ (JÁCOME, 2017).

10 Uma análise sobre essa mudança pode ser lida no artigo: Cultura e religiosidade afro-brasileira: a exclusão do identitário negro no evento "Palmas Capital da Fé", publicado na Revista da ABPN, v. 10, Ed. Especial - Caderno Temático: História e

Após uma nova virada política, a Fundação Cultural de Palmas, sob a gestão da prefeita Cinthia Ribeiro (abril de 2018 - atualmente), voltou a subsidiar as festividades, porém de forma independente da programação oficial de carnaval que continuou com seu viés cristão.

Analisando o fenômeno que culminou na criação da Aldeia TabokaGrande e suas manifestações, é possível traçar um paralelo com o processo de invenção de tradições descrito por Hobsbawm (2012, p. 12-13), ao afirmar que "inventam-se novas tradições quando ocorrem transformações suficientemente amplas e rápidas tanto do lado da demanda quanto da oferta". O percurso históricosocial local, permeado por rupturas e junto à vontade política exercida por gestões da Prefeitura de Palmas, cria a demanda. $O$ ator social, Wertemberg Nunes, munido de habilidades e ferramentas para a criação e materialização de um sistema simbólico, criou a oferta ainda que se a pretensão de se tornar uma tradição de um lugar, como aponta: "(...) ainda não sinto que somos tradição nem mesmo em Taquaruçu" (NUNES, 2017, em entrevista).

Todavia, com as condições criadas, a manifestação fora inventada e, através

Cultura Africana e Afrobrasileira - lei 10.639/03 na escola. 


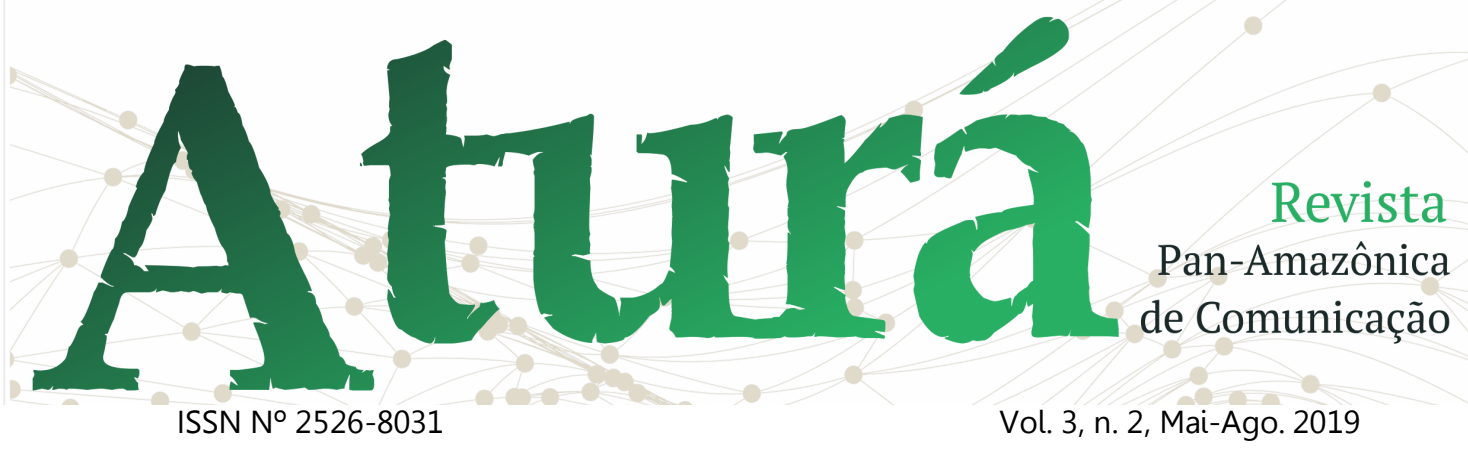

de quase duas décadas, tem sido apropriada pelo discurso midiático da capital - na esfera do jornalismo impresso - e (res)significada de diferentes formas pela população da comunidade local, como está exposto no item a seguir.

Entre Representações: o discurso do sujeito coletivo de Taquaruçu

A memória é mais do que a capacidade de adquirir, guardar e recuperar informações; é um trabalho árduo e contínuo de negociação. Enquanto atividade, ela modela o passado a partir do presente de quem rememora, atribui novo sentido às noções de tempo e espaço e seleciona o que merece ou não ser dito.

Quem toma para si a responsabilidade pelo trabalho da memória são seus guardiões que tem como incumbência serem como um "narrador privilegiado da história do grupo a que pertence e sobre o qual está autorizado a falar" (GOMES, 1996, p. 7). Ele tem sob sua guarda as marcas do passado ao qual se remete, por tornar-se local de convergência entre as histórias vividas por outros do grupo. Esse acervo, que por vezes também se consubstancia em objetos como documentos, fotos etc., inclui relatos meticulosamente recontados e "é a própria identidade do grupo 'materializada': é sua riqueza, poder e emoção" (GOMES, 1996, p. 7).

O conceito de guardião de memória norteou a escolha das vozes que compõem o Discurso do Sujeito Coletivo, o qual é posteriormente analisado com a Análise do Discurso do Sujeito Coletivo (ADSC) (LEFEVRE; LEFEVRE, 2012), que propõe um olhar da população de Taquaruçu sobre a Aldeia TabokaGrande e seus eventos realizadas durante $\mathrm{O}$ carnaval.

A ADSC é uma metodologia de organização e tabulação de dados qualitativos de natureza verbal, obtidos por depoimentos. Consiste em apresentar os resultados sob a forma de um ou vários discursos-síntese, escritos na primeira pessoa do singular, estrutura que propõe expressar o pensamento de uma coletividade, colocando-a como emissor direto da narrativa (LEFEVRE; LEFEVRE; 2012).

O método sistematizado por Lefevre; Lefevre (2012) agrupa as opiniões e expressões individuais que possuem sentido semelhante em categorias semânticas gerais, denominadas discursos-síntese. Nessa pesquisa, as dissonâncias entre os depoimentos colhidos são apresentadas a parte do discurso coletivo, porém, são entendidas como parte integrante do recorte de realidade apreendido pelo estudo. Ou seja, são discrepâncias complementares do processo de memória coletiva. 


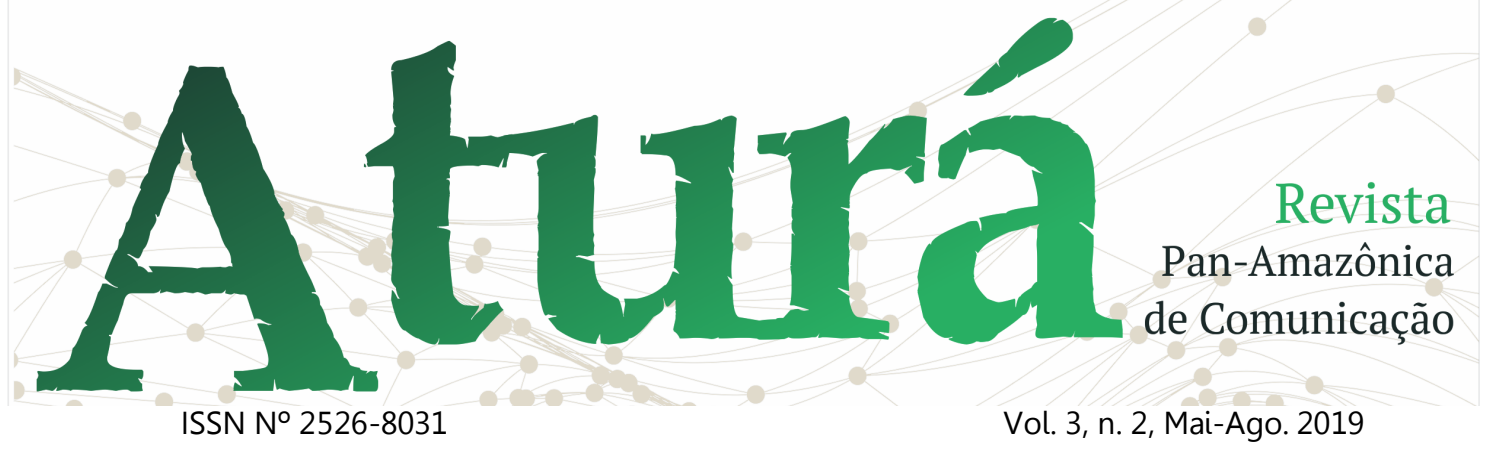

Guiados pela trajetória históricasocial da comunidade de Taquaruçu respaldada em outros estudos, como os de Campos (2015) e Santos (1998), que apresentam tal percurso em maior profundidade - e tendo definido as bases teóricas foram traçados dois grupos geracionais para compor e organizar o corpus do Discurso do Sujeito Coletivo.

O Grupo $A^{11}$ é composto por moradores idosos, os quais, em maior ou menor grau, se ligam à formação da comunidade a partir de suas ondas migratórias com início na primeira metade do séc. XX e à vivência da passagem de uma lógica rural à urbana. Tendo envelhecido no território que hoje é distrito de Taquaruçu, todos experienciaram a instabilidade política e alterações econômicas e sociais catalisadas pela criação do Estado do Tocantins em 1988, bem como viram o surgimento da Aldeia TabokaGrande.

11 O Grupo A é formado por Seu Erotides Rodrigues, nascido em Taquaruçu na década de 1950; Dona Bertolina Pereira da Silva residente da zona rural da comunidade se estabeleceu no núcleo urbano durante a década de 1980, para que suas filhas pudessem frequentar a escola e Seu Benízio Alves de Oliveira integra o grupo dos primeiros migrantes nordestinos a se estabelecerem no vale e começarem na década de 1950 e participou ativamente das primeiras construções que originaram o hoje distrito de Taquaruçu.
Já o Grupo $\mathrm{B}^{12}$ é formado por jovens de vivência eminentemente urbana, que se estabeleceram em Taquaruçu com o distrito sob a égide de Palmas e com a Aldeia já inventada. O ar interiorano e os atributos naturais da comunidade - cachoeiras e clima mais ameno quando comparado a capital foram descritos como atrativos para os novos moradores.

A partir do contato com os sujeitos, realizado em diversas visitas a Taquaruçu, suas narrativas foram apreendidas em entrevistas semiestruturadas com a utilização de dispositivos de gravação de áudio. Os discursos individuais foram transcritos e cruzados, conforme a metodologia de ADSC, para construção de um discurso da coletividade pesquisada.

Em linhas gerais, o Discurso do Sujeito Coletivo, do cruzamento dos relatos de ambos os Grupos A e B, se expressa da seguinte forma, sobre a Aldeia, suas manifestações e seus agentes:

\footnotetext{
12 Grupo formado por Diego Britto, professor da rede pública de ensino e que reside no distrito a partir de 2009; Fernando Magoo, historiador morador de Taquaruçu desde 2012; e Sarah Resplande que a exceção dos demais é nascida no distrito e descende das primeiras famílias a formarem a comunidade, faz graduação em Ciências Sociais na UFT e, assim, transita entre o grupo de pessoas jovens e jovens moradoras.
} 


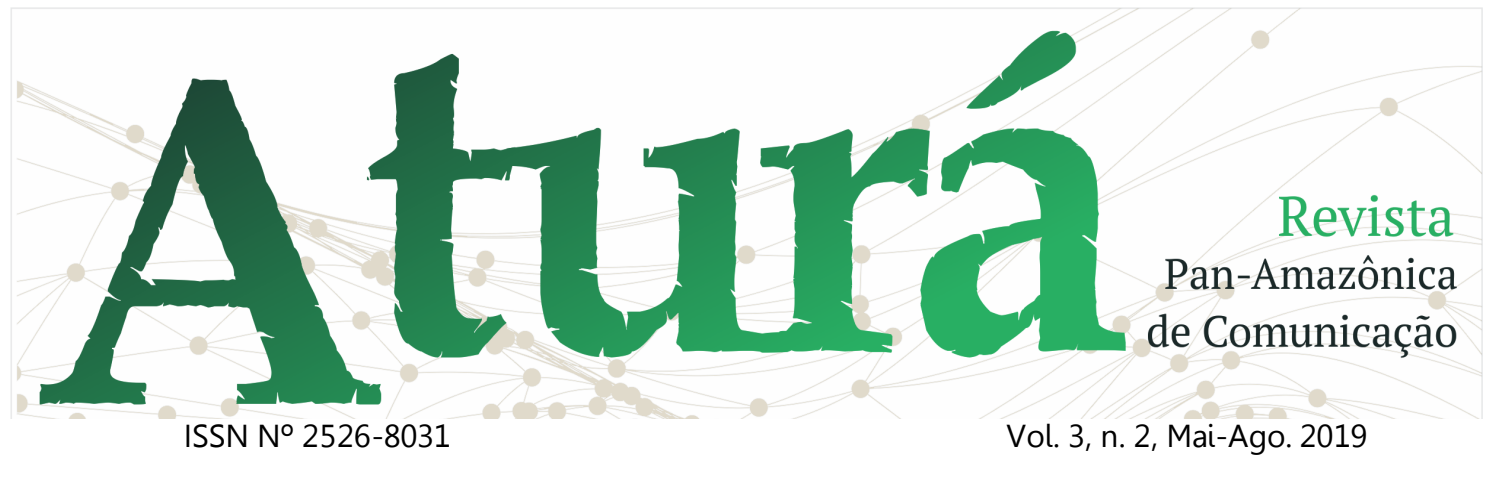

Todos conhecem aquilo, a história é legal, mas ele que inventou. Isso não representa o povo daqui mesmo, porque não existia aqui, o pessoal lá que criou. Então eu acho assim, antes não existia, então eles apresentaram esses bonecos aí por uns anos, mas pra mim não representa Taquaruçu.

Ali para o seguimento dele está bom demais né, para a família dele, para o povo dele que vivencia aquilo ali, pois todo ano eles apresentam esse negócio, então de certa forma acabou virando uma tradição, por que foi o primeiro carnaval que se apresentou por aqui foi o dele e ficou como uma tradição, apesar de não representar o povo de Taquaruçu.

Eles pra mim são boas pessoas, porque tratam a gente bem, conversam com todos, como pessoas são muito boa gente e é válido eles quererem fazer as coisas deles né, o que não pode é o povo vir querer impor isso como tradição do povo de Taquaruçu, por que isso não é. (GUARDIÕES DE MEMÓRIA, 2017, em entrevista ${ }^{13}$ ).

Apesar da confluência de opiniões no que diz respeito às manifestações como representação de Taquaruçu, o discurso se fragmenta quando o tópico é $\mathrm{o}$ ato de frequentar a Aldeia e participar dos ritos. De um lado, há membros de ambos os grupos que participam e não participam dos eventos e, organizando dessa maneira - independentemente de gerações -, seus discursos se articulam da seguinte forma, respectivamente:

13 Discurso do sujeito coletivo construído com base nos pressupostos metodológicos de Levrefe; Levrefe (2012) com base nas entrevistas relatadas.
Eu conheço a Aldeia, eu visito lá, gosto, acho bonito de ver e de participar. Lá a família dele e quem quer participar vivencia a cultura na forma como ele se expressa, nas festas, na arte, em tudo. Isso é real, isso é verdadeiro mesmo.

Conheço, mas não vou lá não. Só vejo por aí as apresentações deles eu não participo. (GUARDIÕES DE MEMÓRIA, 2017, em entrevista).

Ainda sobre a relação construída entre a população e as manifestações da Aldeia, membros do grupo B destacam a religiosidade dos moradores como fator para não aceitação das cerimônias da Aldeia como tradicionais ou características da comunidade:

A questão da religião aqui influencia
muito, muitas pessoas não participam por
causa da religião. Pois são evangélicas14 e
tem certo pudor ou medo de algumas
apresentações, representações. O povo
aqui é muito religioso e se identifica é
com isso, quando você vê no cortejo não
é a mesma coisa, não tem esse mesmo
sentimento das pessoas daqui, tem de
quem conhece a taboka, de quem
conhece a aldeia, a gente sente muito
assim uma energia muito boa, mas as
outras pessoas não sentem muito isso,
ficam, ah tá aqueles bonecos.
(GUARDIÕES DE MEMÓRIA, GRUPO B,
2017, em entrevista).

Pode-se aferir, a partir da análise dos discursos expostos, que, apesar das diferenças entre geração, formação e

14 O trabalho de Campos (2015) apresenta a divisão territorial-religiosa entre católicos e protestantes na fundação do povoado. 


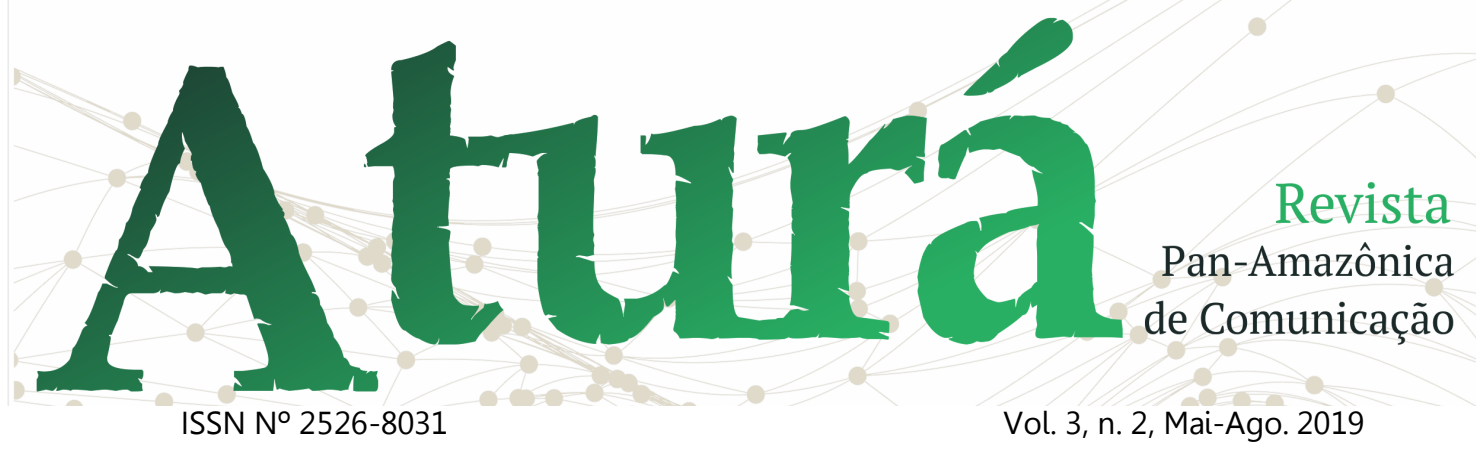

origem que se apresentam entre os guardiões de memória ouvidos, suas falas ecoam entre si, entoando opiniões bem marcadas sobre as manifestações culturais ligadas a Aldeia TabokaGrande serem realizadas por e para um grupo específico que não representa a totalidade da população de Taquaruçu.

Apresentam também o fato do ponto de cultura e seus agentes serem amplamente conhecidos na região, e levantam uma hipótese pertinente sobre a possível ligação entre a religiosidade específica da população e o desenrolar do processo de identificação e legitimação do fenômeno estudado enquanto tradição. Um adendo sobre esse ponto é que algumas vertentes do protestantismo tendem a não aceitar elementos da cultura afro e indígena, tomando-as como coisas ruins, e esses elementos são base das expressões artísticas da Aldeia TabokaGrande desde o nome do local às manifestações culturais que acontece no carnaval.

\section{Versão midiática da Aldeia TabokaGrande: construção de uma narrativa de tradição}

No processo de construção da realidade, nesse movimento constante de fluxos e interações, o discurso midiático ocupa um papel fundamental. Se compreendermos que a memória envolve práticas narrativas e de gerenciamento do

real a partir de práticas discursivas, e que possui ainda uma dimensão imprescindível na constituição das identidades, a mídia toma, por definição, um lugar central, conforme argumenta Enne (2004). Enquanto construto social da realidade, o discurso midiático age como um catalisador e legitimador no processo contemporâneo de invenção de tradição, como assinalado por Hobsbawm (2012).

Desse modo, foi investigado como o discurso midiático formulado por jornais impressos, representando as manifestações culturais promovidas pela Aldeia TabokaGrande durante o período de carnaval entre 2001 e 2017. Para compor a análise documental, foram examinados os arquivos do Jornal do Tocantins (JTo) e do Jornal Primeira Página (JPP). Tal escolha se justifica pela periodicidade regular, antiguidade - em atividade desde 1979 e 1985, respectivamente - e representatividade dos veículos dentro do jornalismo regional tocantinense.

A fundação de ambos os veículos está inserida em um período marcante da história do jornalismo tocantinense que compreende o final da década de 1970 e todo o decênio de 1980, dentro do terceiro processo do Discurso Autonomista do Tocantins (CAVALCANTE, 2003). Em consonância com o momento político, esse período representou também uma efervescência jornalística, 


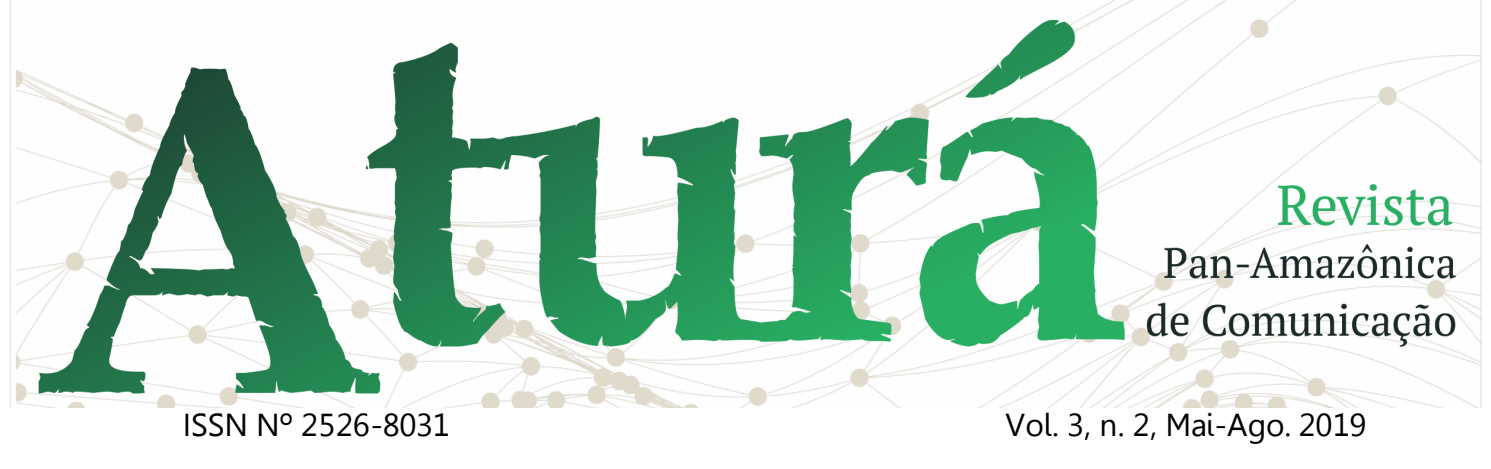

na qual foram abertos, entre os anos de 1975 a 1986, doze veículos de imprensa sediados no território que compreende o Estado atualmente. Tais veículos, impulsionados pelo movimento autonomista, tinham como uma das pautas frequentes a apresentação das diferenças culturais do antigo nortegoiano do centro-sul do Goiás (SILVA, 2003).

Em contato com os arquivos físicos do Patrimônio Cultural de Palmas, do Jornal Primeira Página e das versões digitalizadas do Jornal do Tocantins -, a pesquisa foi conduzida com base nos princípios da Análise de Conteúdo (AC), descritos por Bardin (2009). Para a delimitação do recorte, recorremos à ferramenta de Unidade de Registro (UR) que "[...] é a unidade de significação e corresponde ao segmento de conteúdo a considerar como unidade base, visando $\mathrm{A}$ categorização e a contagem frequencial" (BARDIN, 2009, p. 104).

$\mathrm{O}$ universo material foi refinado a partir da técnica de unidades temáticas. Iniciando com reportagens com o tema carnaval, o recorte foi afunilado para carnaval em Taquaruçu e então para carnaval TabokaGrande, tema de interesse central. Foram encontradas 21 passagens - entre reportagens, notas e fotografias -, em ambos os jornais, correspondentes ao tema central, compondo a amostra ${ }^{15}$. Definida a amostra, realizamos a análise, mesclando os princípios da $A C$ às técnicas da Análise de Discurso, não em sua apresentação clássica, mas na leitura metodológica feita por Orlandi (1999) e Pinto (2002), que busca avaliar o poder discursivo, 0 qual não está contido apenas em quem fala, mas de onde se fala.

É importante salientar que há, na amostra, uma disparidade na proporção de conteúdo entre os jornais, sendo 3 registros pertencente ao JPP e 18 ao JTo. Essa desproporção pode ser compreendida pela diferença de periodicidade entre os veículos, um semanal e o outro diário, e também pela presença de um caderno de cultura no JTo, o caderno Arte \& Vida, que se tornou Magazine a partir de 2017. A presença da editoria específica propicia não apenas a maior quantidade de reportagens, mas também a sua extensão e aprofundamento.

Em linhas gerais, o que se apreende nos arquivos é uma extensiva prática do jornalismo de serviço, ligado essencialmente ao emprego do lide - o quê, quem, quando, onde, como e porquê -, e ao uso de falas institucionais

\footnotetext{
${ }^{15}$ Disponibilizamos um link na íntegra do quadro, no qual estão compiladas todas matérias no link: https://bit.ly/30Vmzcz. Também pode ser acessado em Miranda (2017, p. 62 - 64).
} 


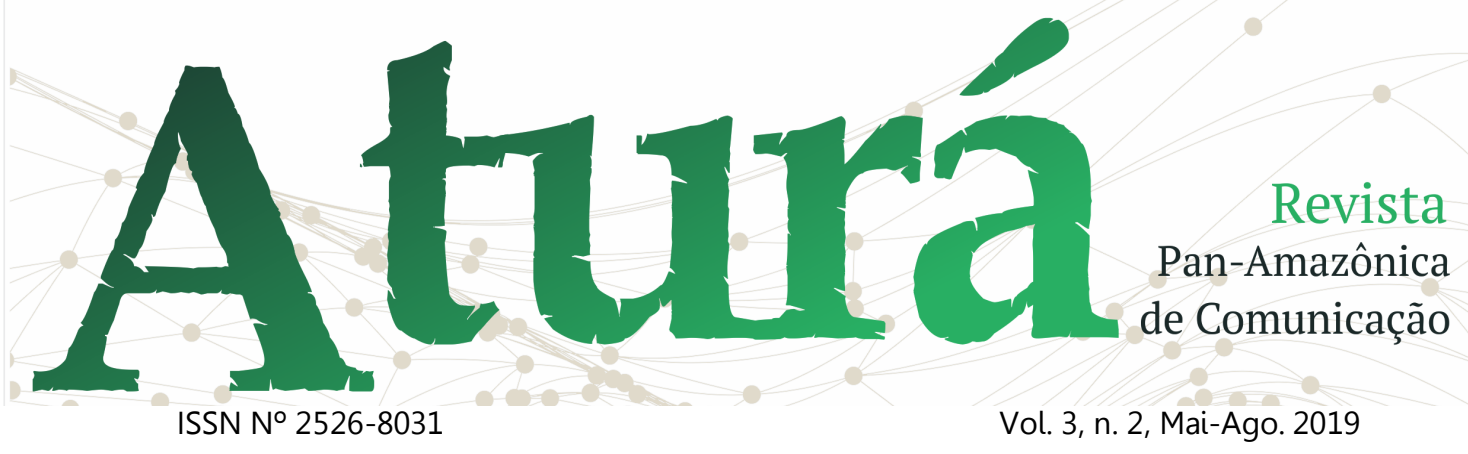

de representantes da Prefeitura e Fundação Cultural de Palmas.

No JPP, a unidade temática Carnaval tem entrada todos os anos. Porém, as unidades específicas carnaval em Taquaruçu e carnaval TabokaGrande tem produção pouco expressiva, com apenas duas passagens referentes à manifestação da Aldeia, e que nem ao menos se dedicavam a mesma em sua totalidade.

Por outro lado, o JTo apresentou 18 passagens que referenciam o tema em questão. A produção se diferencia do primeiro veículo não apenas pela quantidade, mas também por sua estrutura narrativa. É recorrente na amostra referente ao JTo, durante o texto, a inserção de falas de Wertemberg Nunes, mestre de cultura popular e organizador dos eventos. A reportagem na figura abaixo ilustra o panorama geral dos arquivos analisados no Jornal do Tocantins.

Como apontado anteriormente, as festividades relacionadas ao carnaval têm intrínseca ligação com os projetos de gestão da Prefeitura de Palmas, que é sua principal financiadora. Logo, assim como os projetos políticos afetam a programação da festa, também pautam o discurso jornalístico relativo ao tema. Nesse sentido, é possível observar que não houve a cobertura dos veículos pesquisados sobre as manifestações da

Aldeia a partir de 2014, ano em que a prefeitura lança o projeto Palmas Capital da Fé. Os Bonecos Gigantes só voltaram a estampar os impressos palmenses em 2017, ano que conta com três registros na amostra, referentes a duas notas e uma reportagem.

Figura 3 - Matérias Jornal do Tocantins CARNAVAL

Alegria com bonecos mantém tradição

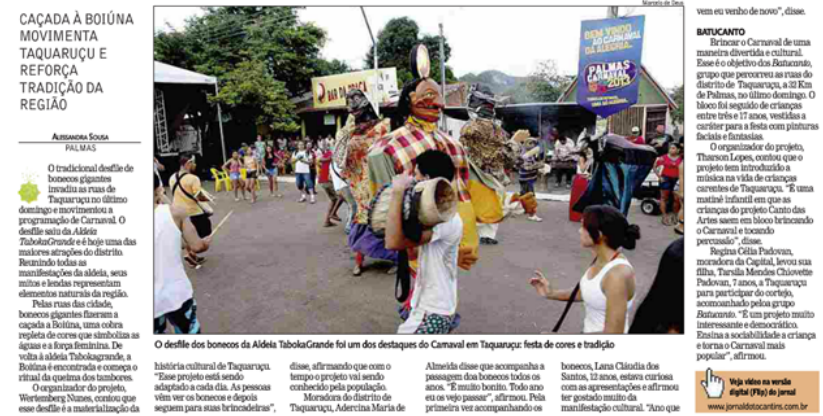

Fonte: Fotografia da matéria veiculada 21 de fevereiro de 2012 e 12 de fevereiro de 2013 no JTo.

Ainda se valendo dos pressupostos metodológicos da AC (BARDIN, 2009), a amostra foi submetida a um exame para averiguar a recorrência da Unidade de Registro Tradição, e suas variações tradições, tradicional, tradicionais etc.. Foram registradas 22 passagens, em edições de 2004 em diante, que se utilizam o termo que tomamos com a UR em questão na composição de sua narrativa, de forma a adjetivar o carnaval promovido pela Aldeia TabokaGrande. 


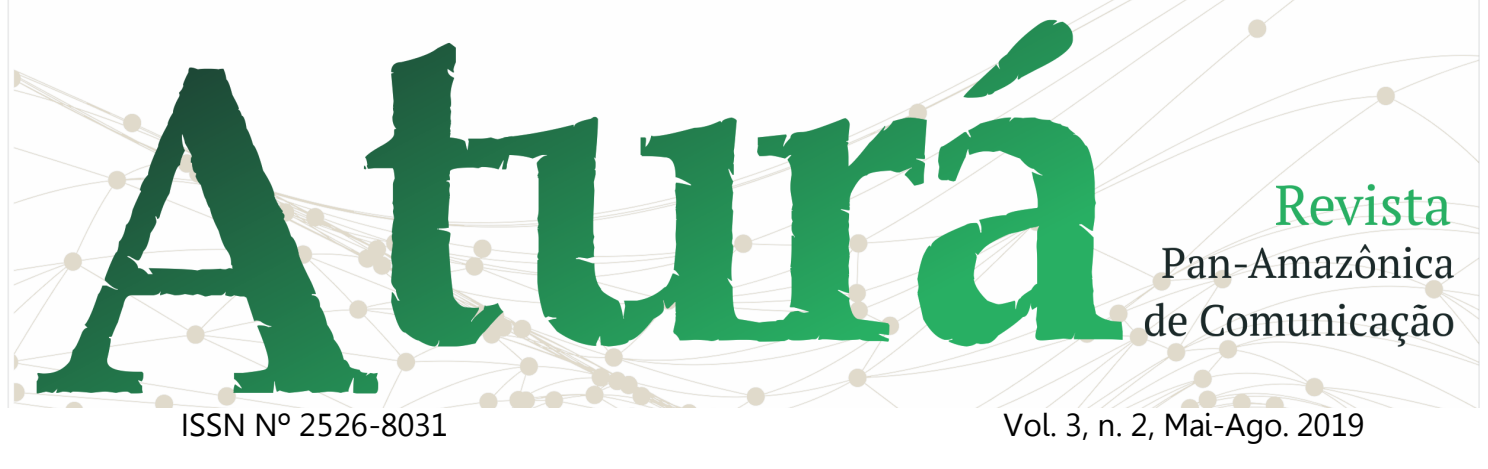

A recorrência do termo "tradição" enquanto adjetivo para as manifestações carnavalescas da Aldeia TabokaGrande evidencia a ação do discurso midiático como componente da construção social da realidade (BERGER; LUCKMANN, 2004), a fim de compor e legitimar o processo de invenção de tradição em curso.

Atrelado a esse processo de invenção está o uso dessa teia simbólica que é a tradição inventada como marcador identitário para Taquaruçu, Palmas e até mesmo Tocantins. $O$ discurso midiático, por sua vez, impõe seus posicionamentos de tal maneira que, em determinado fragmento da amostra, chega a opinar deliberadamente sobre de que forma se materializam os mitos da Aldeia TabokaGrande. O trecho abaixo é extraído da reportagem Taquaruçu também se despede da folia, veiculada em 26 de fevereiro de 2009 no Jornal do Tocantins:

Uma das sugestões para o ano que vem, para que os rituais de encontros entre os bonecos gigantes ocorra na Praça Maracaípe, como nos anos anteriores. O próprio presidente da Fundação Cultural é a favor da iniciativa, mas disse que compete ao diretor da comunidade avaliar a idéia[sic]. 'Na conversa que tive com ele, eu já assinalei que seria muito importante e interessante para eles porque vão expor melhor o trabalho feito. Essa questão é particular dele e a gente tem que respeitar. Acredito que ele vai avaliar essa nossa proposta e vamos ver se no ano que vem, isso muda' declarou. (A. M. A, 2009, p. 1).
O veículo, através dos repórteres e dos entrevistados, opina ostensivamente sobre a localização das festividades e se utiliza da fala de uma figura institucionalizada, no caso, pessoas com cargos públicos para corroborar sua argumentação que se desenvolve de maneira confusa. Esse fato, em conjunto com todo o apreendido na análise da amostra, evidencia o poder que essa instância discursiva toma para si no processo de construção social da realidade.

A partir do corpus analisado, inferimos que os meios de comunicação de massa, na mídia impressa, em especial o veículo JTo, utiliza de sua posição para legitimar as manifestações da Aldeia TabokaGrande como símbolo e marco de representação identitária para a comunidade de Taquaruçu. Mas que, independente da forma como seja representada pela imprensa, a sua população não percebe os ritos e, dessa maneira, demonstrando a complexidade envolta nos processos de construção de identidade cultural e invenção de tradição.

\section{Considerações finais}

Nesta narrativa, em forma de artigo, buscamos apreender a três diferentes dimensões de outras narrativas tecidas a partir de fenômeno social específico para descortinar aspectos 


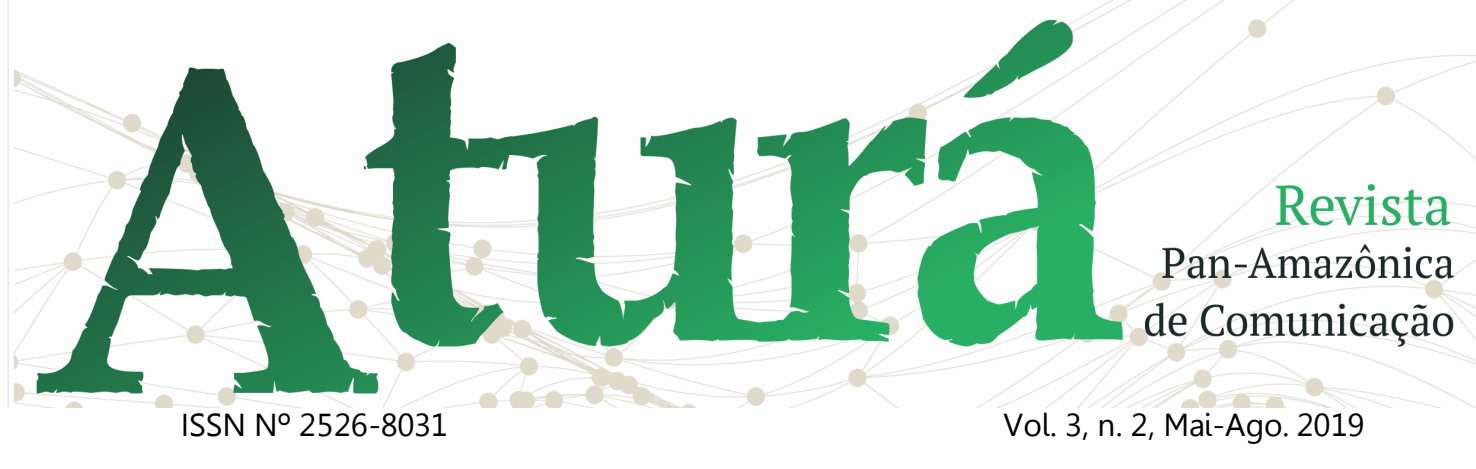

envoltos na construção social da realidade que dizem respeito à construção da identidade cultural e ao processo contemporâneo de invenção de tradições (BERGER; LUCKMAN, 2004; HOBSBAWM, 2012) do e no distrito de Taquaruçu. No fenômeno que compõe a criação da aldeia TabokaGrande e a realização de seus rituais nas últimas duas décadas, houve uma marcação simbólica, dentro do processo de construção da identidade cultural, na qual foram eleitos alguns elementos para serem tomados como representantes da identidade cultural de um lugar, Taquaruçu, enquanto distrito e adendo de Palmas.

Dessa maneira, trata-se de um elemento cultural instituído a partir de planos de governo, que possuem sua lógica própria e estão intrinsecamente ligados às gestões e seus representantes que se modificam conforme a alternância de mandatos. A partir disso, se estão ligados a planos de governo, são atrelados a planos de poder e, assim, corroboram com a categoria de invenção de Hobsbawm (2012), isto é, são invenções de tradição, pois é dentro de um campo teórico que aponta para grupos privilegiados que conseguem eleger elementos que se fazem tradição e ainda inventam uma narrativa que se pretende coerente e convincente para tanto.

Essa determinação exógena fica explícita à medida que se entrecruzam as afirmativas do mentor da Aldeia, Wertemberg Nunes, e o Discurso do Sujeito Coletivo, formulado com base nos relatos de guardiões de memória da comunidade de Taquaruçu. Assim, observamos como confluem para uma apreensão da Aldeia como elemento não representativo da comunidade na qual está inserida.

Os Tawera, responsáveis pela Aldeia, não se pretendiam ser as manifestações identitárias de Taquaruçu, estando ligados a uma lógica mais familiar e pessoal. A população também não percebe dessa forma, embora em uma perspectiva relacional seja levada a considerar como tradição o fenômeno, por sua perpetuação nos últimos dezenove anos dentro de um estado com apenas três décadas.

Entretanto, corroborando a invenção de tradição e em consonância com a categoria de Berger; Luckmann (2004) que apontam o discurso midiático como um construto social da realidade, os meios de comunicação de massa jornais impressos analisados -, sobretudo o Jornal do Tocantins, constroem uma narrativa que aponta a Aldeia TabokaGrande e seus rituais como uma tradição de Taquaruçu, Palmas e até mesmo do Tocantins. 


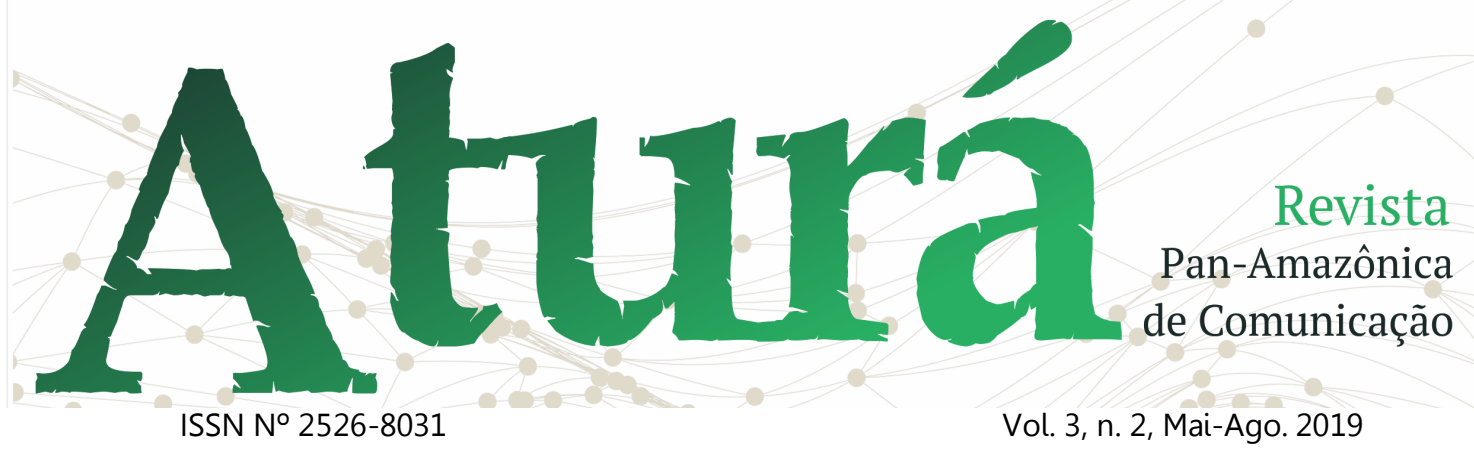

Ao longo do percurso, observamos o ator social, que age como produtor cultural, perder o não manter do monopólio representativo de suas obras à medida que a manifesta na esfera pública, lugar em que seus sistemas simbólicos passam a serem apreendidos e representados das maneiras mais diversas.

Isso posto, deve-se conhecer os meandros que regem a tessitura do discurso midiático para assim realizar uma leitura mais crítica e consciente desse. É essencial observá-lo como uma estrutura de representação, que se apropria de um ideal de realidade já fragmentado para construir sua narrativa, que é, em essência, parcial.

Em síntese, a partir do fenômeno apreendido é possível perceber que, apesar de as instâncias do poder público possuírem, em certa medida, os recursos e ferramentas para propiciar a invenção de tradições, o processo que envolve a construção da identidade cultural é mais profundo e complexo do que nossos representantes políticos normalmente 0 tomam, sendo, portanto, dificilmente demandado de forma exógena.

\section{Referências}

A.M.A. Taquaruçu também se despede da folia. Jornal do Tocantins, Palmas 26, fev., 2009. Caderno Arte \& Vida.

ANJOS, Ana Carolina Costa de. Do Girassol ao Capim Dourado: apropriação e ressignificação de elementos naturais na narrativa identitária do Estado do Tocantins. Porto Alegre, RS: Editora Fi, 2017.

[Autoria desconhecida]. Os Bonecos da Aldeia TabokaGrande 1 [200?]. 1 fotografia color.

Acervo particular Acervo da Aldeia TabokaGrande.

BARDIN, Laurence. Análise de Conteúdo. 5. Ed. Lisboa: Edições 70, 2009.

BERGER, Peter; LUCKMANN, Thomas. A construção social da realidade: tratado da sociologia do conhecimento. Tradução de Floriano Souza Fernandes. 24 Ed. Petrópolis (RJ), 2004.

CAMARO, Ana Amélia; ABRAMOVAY, Ricardo. Êxodo Rural, Envelhecimento e Masculinização no Brasil: panorama dos últimos 50 anos. Texto para discussão n. 62. IPEA, 1999.

CAMPOS, Sandro Cunha. Histórias de Taquaruçu: do campesinato ao bucólico, trajetórias e discursividades em um distrito de Palmas (TO). 2015. (144p). Dissertação. (Mestrado em Ciências do Ambiente) Universidade Federal do Tocantins, Palmas, 2015.

CARVALHO, Francisquinha Laranjeira. Taquaruçu. Goiânia: Kelps, 2010.

CAVALCANTE, Maria do Espírito Santo Rosa. O discurso autonomista do Tocantins. Goiás: Ed. da UCG, 2003.

ENNE, Ana Lúcia S. Memória, identidade e imprensa numa perspectiva relacional. In: 


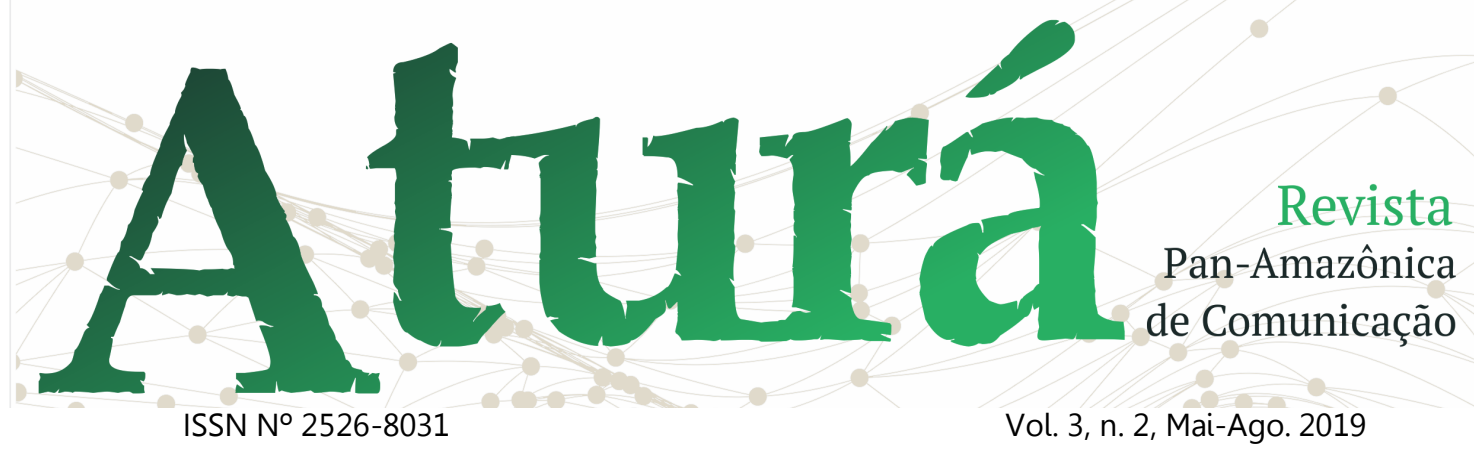

Revista Fronteiras: estudos midiáticos, n. 2, jul./dez., 2004.

FERNANDES, Renata Sieiro. A memória dos lugares, dos objetos e os guardiões de memória na educação não-formal. In: História Oral, v.8, n.2, jul./dez., 2005, p. 169-193.

GOIAS. Lei n. 10.419 , de $1^{\circ}$ de janeiro de 1988. Dispõe sobre a criação do Município de TAQUARUSSU DO PORTO e dá outras providências. Disponível em:

http://www.gabinetecivil.go.gov.br/leis ordin arias/1988/lei 10419.htm. Acesso em 06jul. 2019.

GOMES, Ângela de Castro. A guardiã de memória. In: Revista do Arquivo Nacional, v.9, n.1/2, jan./dez., Rio de Janeiro, 1996, p.17-30.

JÁCOME, Wédila. Palmas será a Capital da Fé no período de Carnaval e promete reunir um público de mais de 180 mil. In: Portal Palmas, Agência de Turismo, 31 jan. 2017. Disponível em:

http://www.palmas.to.gov.br/secretaria/agenc ia-de-turismo/noticia/1503789/palmas-seraa-capital-da-fe-no-periodo-de-carnaval-epromete-reunir-um-publico-de-mais-de-180mil/>. Acesso em: 06 jul. 2019.

HOBSBAWM, Eric J.; RANGER, Terence (org.). A Invenção das Tradições. Tradução de Celina Cardim Cavalcante, 2. Ed., São Paulo: Paz e Terra, 2012.

LEFEVRE, Fernando; LEFEVRE, Ana Maria. Pesquisa de representação social: Um enfoque qualiquantitativo: a metodologia do Discurso do Sujeito Coletivo. Brasília: Liber Editora, 2. Ed., 2012.

MARCONI, $M$ de A.; LAKATOS, E. M.. Fundamentos da Metodologia Científica. 5. Ed. São Paulo: Atlas - S.A, 2003.

MIRANDA, Anna Karolyne Souza. Cerimônia da Queima de Tambores em dois atos 2. [2017]. 1 fotografia color.

NUNES, Wertemberg. Entrevistas 4 [2017]. Entrevistadora Anna Karolyne Souza Miranda, Taquaruçu-Palmas, 2017. 5 arq.

ORLANDI, Eni. Análise de Discurso: princípios e procedimentos. Campinas: Pontes, 1999.

SANTOS, Joana Euda Barbosa. Taquaruçu: reconstruindo uma história através da memória (1940-1960). Dissertação (Mestrado em História), Universidade Federal de Pernambuco - UFPE, Recife, 1998.

SILVA, Valéria Cristina Pereira da. Palmas, a última capital projetada do século XX: uma cidade em busca do. São Paulo: Cultura Acadêmica, 2010.

SILVA, Otávio Barros. História da Imprensa no Tocantins. Palmas, To: Empresa Tocantinense de Comunicação, 2003.

PINTO, Milton José. Comunicação e Discurso: Introdução à análise de discursos. 2. Ed., São Paulo: Hacker Editores, 2002.

PALMAS. Lei n. 28 de 29 de dezembro de 1989. Transfere a sede do município De Taquarussu do Porto para Palmas. Disponível em:

https://leismunicipais.com.br/a/to/p/palmas/l ei-ordinaria/1989/2/28/lei-ordinaria-n-281989-transfere-a-sede-do-municipio-detaquarussu-do-porto-para-palmas-1989-1229-versao-compilada. Acesso em 06 jul. 2019. 